\title{
L. V. BRUN
}

National University of Pharmacy

\section{EXPERIMENTAL STUDY OF THE NONSTEROIDAL ANTI-INFLAMMATORY DRUGS APPLICATION UNDER USING LOW-INTENSITY INFRARED LASER RADIATION}

Topicality. The combined application of nonsteroidal anti-inflammatory drugs (NSAIDs) and low-intensity infrared laser radiation (LIIRLR) for treatment of osteoarthrosis has remained an actual task.

Aim to study the NSAIDs usage under LIIRLR application in experiments in rats.

Materials and methods. The time for LIIRLR application (15 min after drug administration) was chosen according to our previous studies on diclofenac sodium (DNa) pharmacokinetics in rats blood plasma. To study the NSAIDs application at the influence of LIIRLR, white beedless male rats $(n=15)$ of 250-300 g were used in the experiments. The animals were divided into 3 groups. Rats of group the 1 were received purified water (per os) and exposed to LIIRLR. Rats of group the 2 were received $\mathrm{DNa}$ at a dose of $\mathrm{ED}_{50}$ (per os, $8 \mathrm{mg} / \mathrm{kg}$ ). Rats of group the 3 were influenced of LIIRLR and in $15 \mathrm{~min}$ received DNa (per os, $8 \mathrm{mg} / \mathrm{kg}$ ). For DNa extraction from rat plasma samples, the method of solid-phase extraction was used. Concentration of DNa was determined by method of high-performance liquid chromatography (HPLC).

Results and discussion. It was established that at the combined use LIIRLR and DNa the drug concentration in the rats blood serum was 1.7 fold higher in comparison to DNa application alone.

Conclusions. It is proved, that the method of combine application of LIIRLRand NSAIDs (in $15 \mathrm{~min}$ ) was more effective than the use of NSAIDs alone.

Key words: osteoarthrosis; nonsteroidal anti-inflammatory drugs; diclofenac sodium; glucosamine; low-intensity infrared laser radiation; lasertherapy; high-performance liquid chromatography

\section{Л. В. Брунь}

Експериментальне дослідження застосування нестероїдних протизапальних препаратів при використанні низькоінтенсивного інфрачервоного лазерного випромінювання

Актуальність. Комбіноване застосування нестероїдних протизапальних препаратів (НПзП) і низькоінтенсивного інфрачервоного лазерного випромінювання (НIЛВ) для лікування остеоартрозу є актуальним завданням.

Мета роботи - вивчити застосування НПЗП при використанні НІЛВ в експерименті на щурах.

Матеріали та методи. Час використання НІЛВ (15 хв після введення препарату) був встановлений при дослідженні фармакокінетики диклофенаку натрію (ДNa) у плазмі крові щурів. Для вивчення застосування НПзП при впливі НІЛВ були використані нелінійні білі щури-самці (n = 15) масою 250-300 г. Тварини в експерименті були розділені на 3 групи. Першій групі щурів вводили воду очищену (per os) та піддавали впливу НІЛВ. Другій

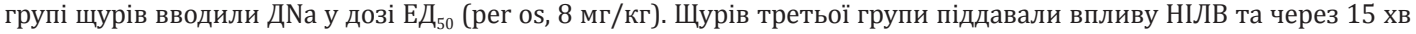
вводили ДNa (per os, 8 мг/кг). Для екстрагування ДNa із зразків плазми крові щурів був використаний метод твердофазової екстракції. Концентрацію ДNа визначали за методом високоефективної рідинної хроматографії (BEPX).

Результати та їх обговорення. Встановлено, що при схемі комбінованого використання НІЛВ та ДNа по відношенню до застосування ДNа концентрація препарату у плазмі крові щурів підвищувалась в 1,7 рази.

Висновки. Доведено, що наведений метод комбінованого використання НІЛВ та НПЗП (через 15 хв) є більш ефективним, ніж застосування НПЗП.

Ключові слова: остеоартроз; нестероїдні протизапальні препарати; диклофенак натрію; глюкозамін; низькоінтенсивне інфрачервоне лазерне випромінювання; лазеротерапія; високоефективна рідинна хроматографія

Л. В. Брунь

Экспериментальное исследование применения нестероидных противовоспалительных препаратов при использовании низкоинтенсивного инфракрасного лазерного излучения

Актуальность. Комбинированное применение нестероидных противовоспалительных препаратов (НПВП) и низкоинтенсивного инфракрасного лазерного излучения (НИЛИ) для лечения остеоартроза является актуальной задачей.

Цель работы - изучить применение НПВП при использовании НИЛИ в эксперименте на крысах.

Материалы и методы. Время применения НИЛИ (15 мин после введения препарата) было установлено при исследовании фармакокинетики диклофенака натрия (ДNa) в плазме крови крыс. Для изучения применения НПВС при воздействии НИЛИ были использованы нелинейные белые крысы-самцы (n = 15) массой 250-300 г. Животные в эксперименте были разделены на 3 группы. Первой группе крыс вводили воду очищенную (per os) и

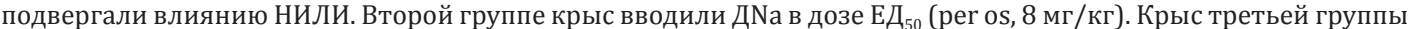
подвергали влиянию НИлИ и через 15 мин вводили ДNa (per os, 8 мг/кг). Для извлечения ДNа из образцов плазмы крови крыс был использован метод твердофазной экстракции. Концентрацию ДNа определяли с помощью метода высокоэффективной жидкостной хроматографии (ВЭЖХ). 
Результаты и их обсуждение. Установлено, что при схеме комбинированного использования НИЛИ и ДNа по отношению к применению ДNа концентрация препарата в плазме крови крыс повышалась в 1,7 раза.

Выводы. Доказано, что приведенный метод комбинированного использования НИЛИ и НПВП (через 15 мин) более эффективный, чем применение НПВП.

Ключевые слова: остеоартроз; нестероидные противовоспалительные препараты; диклофенак натрия; глюкозамин; низкоинтенсивное инфракрасное лазерное излучение; лазеротерапия; высокоэффективная жидкостная хроматография

\section{INTRODUCTION}

Diseases of musculoskeletal system (MSS) and connective tissue are widespread in many countries of the world; they lead to decreased working capacity, worsening of the quality of life, social disadaptation, and, in the consequence, disability. Osteoarthrosis (OA) is leading as for incidence among this category of diseases. At least $20 \%$ of world population suffer from it. That is why its treatment is a medical and social problem that is urgent all over the world $[1,2]$.

There are various drugs and methods of treatment for MSS and connective tissue diseases. Nonsteroidal antiinflammatory drugs (NSAIDs) constitute one of the central positions in therapy of these diseases and are most widely used in modern medicine, clinical practice, and pharmacy [2, 4].

Diclofenac sodium (DNa) remains the reference drug of NSAIDs group [1, 3, 4]. However, in spite of a great number of treatment schemes used, pharmacological correction of MSS and connective tissue diseases is an important and urgent task, which calls for new methods of treatment $[1,2]$.

It has been found that physical factors can potentiate drugs' action. Due to this fact, use of low-intensity infrared laser radiation (LIIRLR) attracts the attention of scientists. This method of treatment has analgesic, anti-inflammatory, pain alleviating, regenerating, desensitization, immune-corrective, hypocholesterolemic, bactericidal, and bacteriostatic effects; it also improves local blood circulation $[1,4,5]$.

Thus, the possibility of combined use of NSAIDs and LIIRLR for treatment of MSS and connective tissue diseases is an urgent and well-grounded task; it will allow to improve the results of treatment of OA patients.

The aim of this work is to study NSAIDs use along with LIIRLR in the experiment in rats.

\section{MATERIALS AND METHODS}

Diclofenac sodium (DNa), sodium 2-[(2,6 - dichlorophenyl) amino] phenyl] acetate, has marked anti-inflammatory, analgetic, as well as moderate antipyretic activities [3]. Substance of DNa manufactured by Borshchahivskiy Chemical-Pharmaceutical Plant (BCPP), Ukraine (batch No.20040609) was used for the study. Substance of DNa manufactured by "Amoli Organics Ltd" (batch No. 20061013) was used as a working reference standard (WRS).

Identification and quantitative determination of $\mathrm{DNa}$ in the substance of DNa were carried out by most sen- sitive method of high-performance liquid chromatography (HPLC) $[6,7]$. This method was used to determine concentrations of the test substance at all stages of the study.

Animals used in the experiment: white beedless male rats of the population of experimental biological clinics of the State Enterprise "Sytenko Institute of Spine and Joint Pathology of the National Academy of Medical Sciences of Ukraine".

Conduct of experiments was approved by the local committee on bioethics of the State Enterprise "Sytenko Institute of Spine and Joint Pathology of the National Academy of Medical Sciences of Ukraine" (protocols No. 44 dated October 22, 2007; No. 81 dated December 20, 2010). Work with animals was carried out according to Directive of the European Parliament and European Council 2010/63 EU.

The time of LIIRLR use and the time of animal sacrifice have been determined in our previous studies on pharmacokinetics of DNa in rat plasma by method of high-performance liquid chromatography (HPLC) [8].

LIIRLR was carried out in 15 min after drug administration with laser therapeutic unit "Mustang" set as follows: wavelength is $0.89 \mu \mathrm{m}$, pulse power is $7-8 \mathrm{~W}$, pulse frequency is $3.000 \mathrm{~Hz}$, duration of the session is $3 \mathrm{~min}$ $42 \mathrm{sec}$, radiation dose is $0.3 \mathrm{~J}$ (calculated by specialists of National Research Center "Metrology Institute", Kharkiv, Ukraine). The apparatus was used by contact along the posterior surface of the rat knee joint with preliminary removed hair [9].

To study concomitant use of NSAIDs and LIIRLR, we selected 15 male rats with body weight of $250-300 \mathrm{~g}$, which were kept according to according to sanitary norms on a standard diet [10]. Experimental animals were subdivided into 3 groups, 5 rats per group. DNa was diluted in purified water and administered in the same volume at a dose of $\mathrm{ED}_{50}$ (per os, $8 \mathrm{mg} / \mathrm{kg}$ of animal body weight). Animals of group 1 received purified water (per os, $0.5 \mathrm{~mL}$ per $100 \mathrm{~g}$ of animal body weight) and were exposed to LIIRLR. Animals of group 2 received per os DNa at a dose of $\mathrm{ED}_{50}$ [10]. Animals of group 3 were subjected to the influence of LIIRLR and in 15 min received DNa (per os, $8 \mathrm{mg} / \mathrm{kg}$ ). Animals were sacrificed in $60 \mathrm{~min}$ after drug introduction [8].

Blood was sampled in the quantity of 7-10 $\mathrm{ml}$ into labeled test-tubes that were heparinized. Blood samples were centrifuged ( $3.000 \mathrm{rpm}, 15 \mathrm{~min}$ ), and plasma was obtained. The interval between blood sampling and its processing did not exceed $5 \mathrm{~min}$. Before analysis, plasma samples were kept at $-80^{\circ} \mathrm{C}$. 


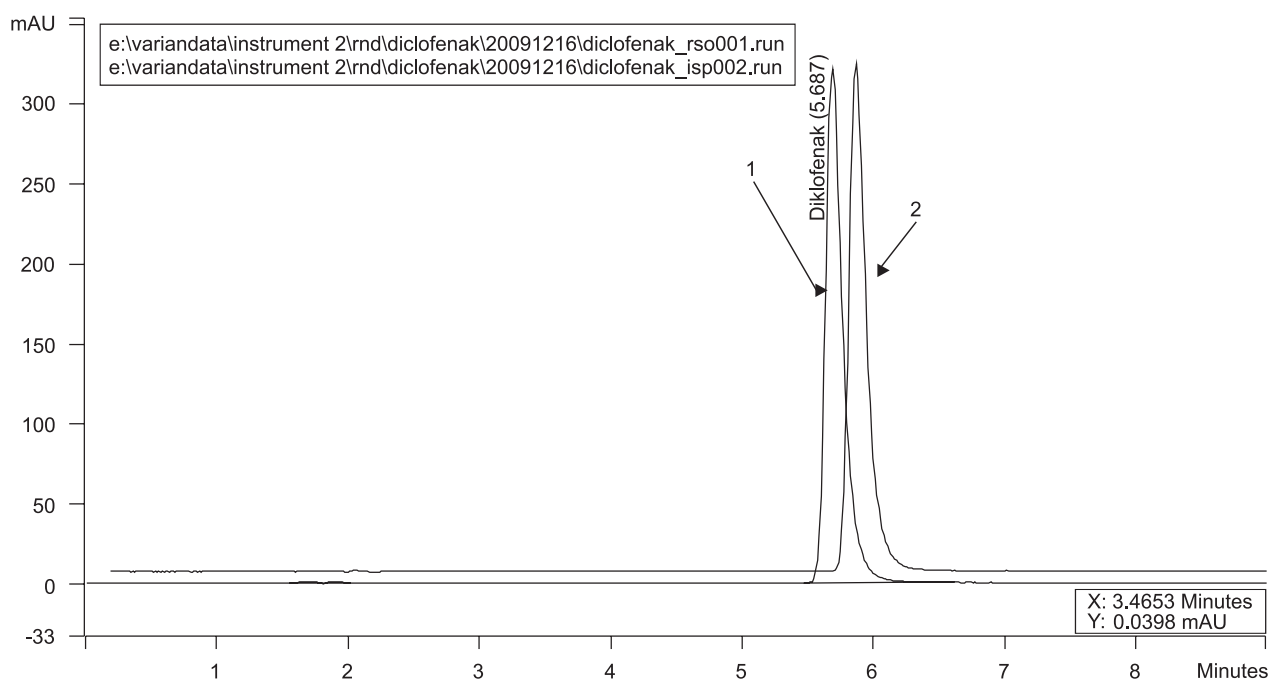

Fig. 1. Chromatograms of diclofenac sodium substance samples. 1 - chromatogram of DNa manufactured by "Amoli Organics Ltd"; 2 - chromatogram of DNa used in the experiment as WRS manufactured by BCPP

For extraction of DNa from rat plasma samples, a method of solid-phase extraction was used [7]. Cartridges Supel ${ }^{\mathrm{TM}}$-Select HLB SPE (Supelco) $30 \mathrm{mg} / 1 \mathrm{ml}$ were used for work. The method had been modified due to microconcentrations of the active substance during previous stages of the complex study [11].

Statistic processing of experimental data obtained was carried out with software STATISTICA (StatSoft Inc., the USA). Reliability of the results obtained was assessed at the level of significance not less than $95 \%(p \leq 0.05)$ [12].

\section{RESULTS AND DISCUSSION}

Confirmation and determination of quantitative determination of $\mathrm{DNa}$ (manufactured by $\mathrm{BCPP}$ ) in rat plasma were carried out in comparison to DNa WRS manufactured by "Amoli Organics Ltd". Chromatograms of DNa substance samples obtained under the same conditions are presented in Fig. 1.

Retention time of DNa in the chromatogram of the test sample of the solution (5.673 $\mathrm{min}$ ) corresponds to that of DNa in the chromatogram of DNa WRS (5.673 min), so the sample provided is DNa substance. In the result of the studies conducted, quantitative content of DNa and suitability of the dose studied. Actual dose of DNa during study conduct is $8 \mathrm{mg} / \mathrm{kg}$.

Chromatogram of the control solution (rat's blood plasma), which were exposed to LIIRLR is shown in Fig. 2.

When studying plasma concentration of DNa in animals of group 2, which received DNa per os ( $8 \mathrm{mg} / \mathrm{kg}$ ), it was determined to be $2.36 \pm 1.10 \mu \mathrm{g} / \mathrm{mL}$. Plasma concentration of DNa in animals of group 3 subjected to the influence of LIIRLR and in $15 \mathrm{~min}$ received DNa per os $(8 \mathrm{mg} / \mathrm{kg}$ ) was $4.08 \pm 1.96 \mu \mathrm{g} / \mathrm{mL}$. Typical chromatograms of the test solution and reference solution are presented in Fig. 3, 4.

Thus, quantitative content of DNa in the substance of DNa and suitability of the dose studied ( $8 \mathrm{mg} / \mathrm{kg}$ ) were confirmed. It was established that under the scheme of the combined use of LIIRLR and DNa (per os, in $15 \mathrm{~min}$ ) in comparison to the group of animals with $\mathrm{DNa}$ (per os) administration, the concentration of drug in blood plasma of rats was increased in 1.7 times. This shows the effectiveness of the combined use LIIRLR of and NSAIDs.

The results obtained indicate to the fact that concomitant use of NSAIDs and LIIRLR potentiate the ac-

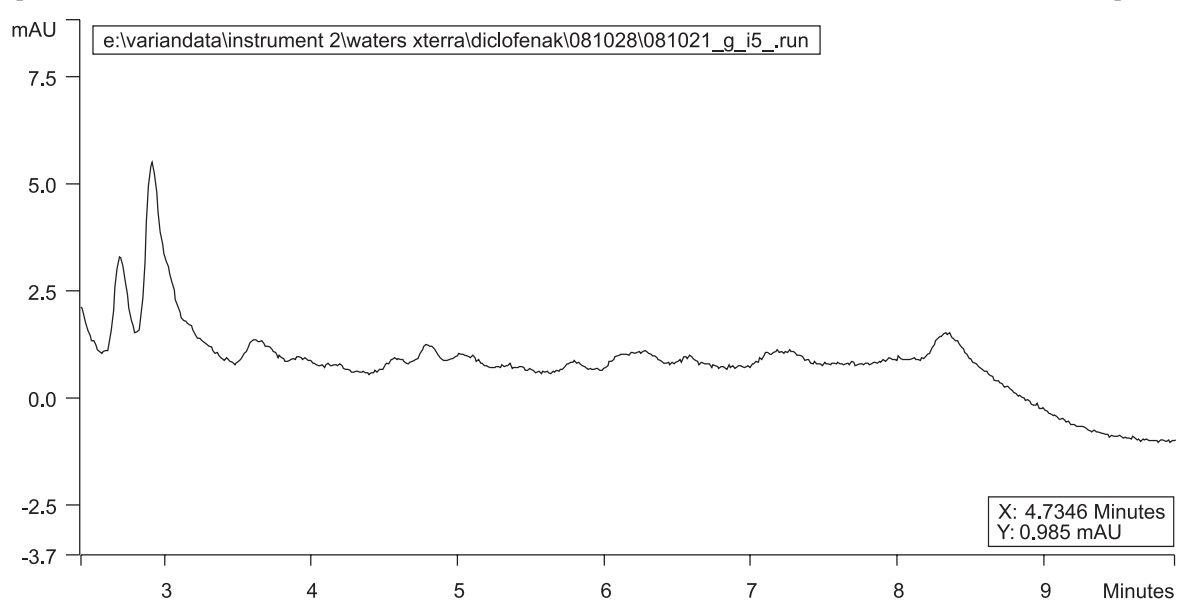

Fig. 2. Chromatogram of the control solution (blood plasma of rats, which were exposed to LIIRLR) 


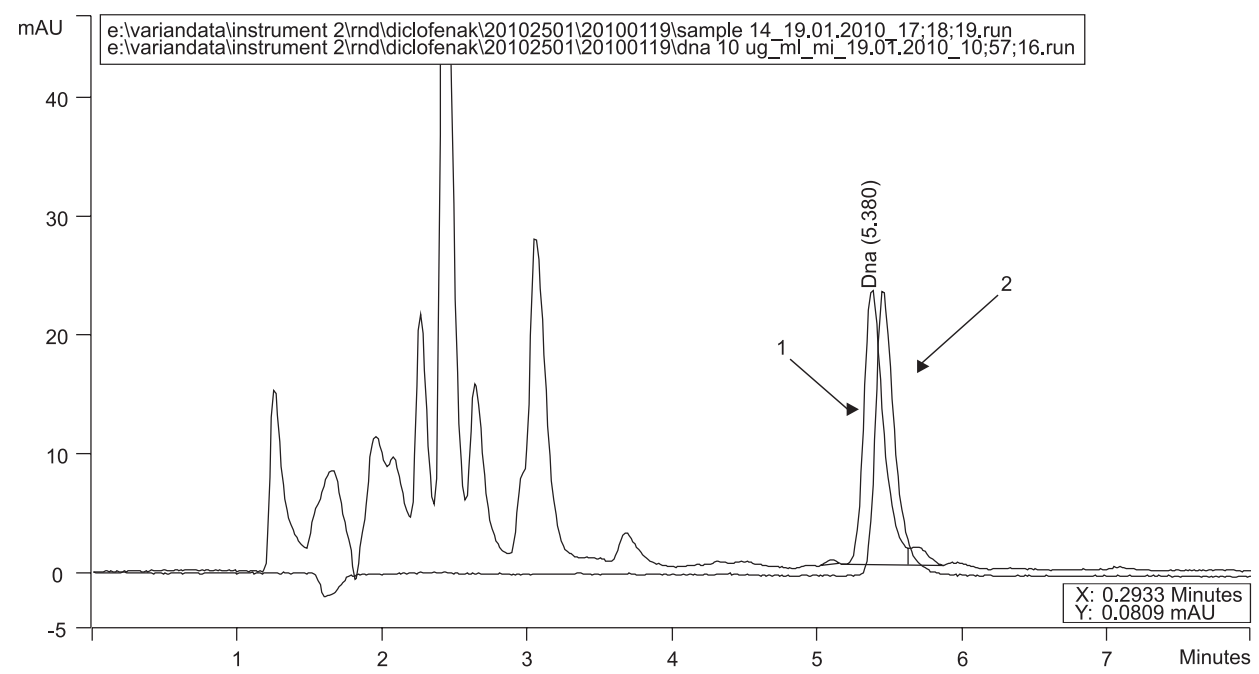

Fig. 3. Chromatograms of the reference solution and test solution from plasma of rats that received DNa per os. 1 - chromatogram of the reference solution; 2 - chromatogram of the test solution from plasma of rats that received DNa per os

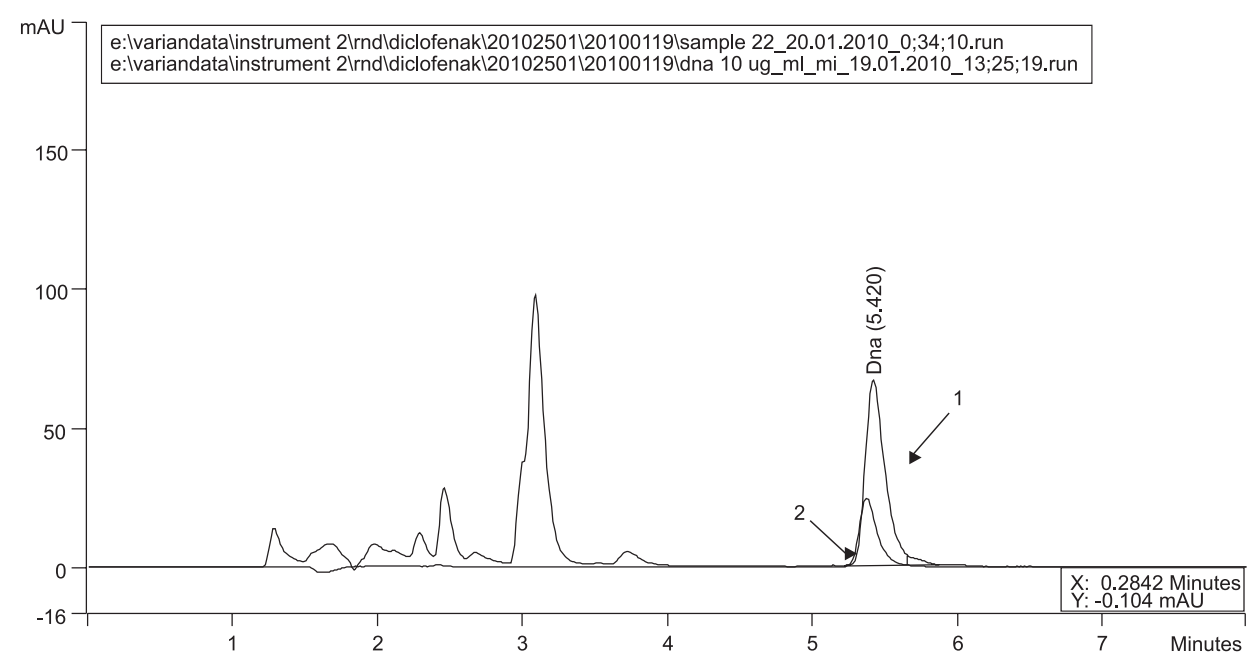

Fig. 4. Chromatograms of the reference solution and test solution from plasma of rats that subjected to the influence of LIIRLR and in 15 min received DNa per os. 1 - chromatogram of the reference solution; 2 - chromatogram of the

test solution from plasma of rats that subjected to the influence of LIIRLR and in 15 min received DNa per os

tion of drugs. This allows to decrease the dose, influence intake and duration of NSAIDs' action in the organism, decrease the frequency of their administration, and is a subject for further study.

\section{CONCLUSIONS}

Use of NSAIDs along with LIIRLR has been studied in experiments on rats. It is proved, that the method of com- bine application of LIIRLR and NSAIDs (per os, in $15 \mathrm{~min}$ ) was more effective than the use of NSAIDs alone. The scheme of concomitant indication of LIIRLR and NSAIDs studied will be used for further preclinical and clinical studies, as well as for improvement of the quality of treatment in osteoarthrosis patients.

Conflicts of Interest: authors have no conflict of interest to declare.

\section{REFERENCES}

1. Корж, Н. А. Форум экспертов по ступенчатой терапии остеоартроза / Н. А. Корж // Ортопедия, травматол. и протезирование. - 2014. № 3. - C. $144-45$.

2. de Rezende, M. U. Current concepts in osteoarthritis / M .U. de Rezende, G. C. de Campos, A. F. Pailo // Acta Ortop. Bras. - 2013. - Vol. 21, Issue 2. - P. 120-122.

3. Компендиум 2015 - лекарственные препараты / под ред. В. Н. Коваленко, А. П. Викторова. - К. : Морион, 2015. - 2320 с.

4. Остеоартроз: консервативная терапия: моногр. / Н. А. Корж, А. Н. Хвисюк, Н. В. Дедух и др. ; под ред. Н. А. Коржа, Н. В. Дедух, И. А. Зупанца. Х. : Золотые страницы, 2007. - 424 с.

5. Москвин, С. В. Основы лазерной терапии / С. В. Москвин, В. А. Буйлин. - М. : Пирамида, 2006. - 256 с. 
6. Kamath, B. V. High-perfomance liquid chromatographic method for the determination of diclofenac in human plasma and urine / B. V. Kamath, K. Shivram, A. C. Shah // J. Chromatogr. - 1993. - Vol. 12, Issue 3. - P. 324-329.

7. United States Pharmacopea / Official Monographs. - 1995. - P. 546.

8. Brun, L. V. Pharmacokinetic study of diclofenac sodium in rat plasma by high-performance liquid chromatography / L. V. Brun, V. I. Macolinets, S. N. Gubar // Укр. біофармац. журн. - 2016. - № 4 (45). - С. 62-70.

9. Пат. на корисну модель 60579 Україна, МПК (2006) А 61 N 5/067, А 61 К 31/196, А 61 К 31/726. Спосіб комплексного консервативного лікування хворих на остеоартроз суглобів нижніх кінцівок / М. О. Корж, В. І. Маколінець, Н. В. Дєдух та ін.; заявник і патентовласник ДУ «Інститут патології хребта та суглобів ім. проф. М. І. Ситенка НАМН України». - № u 201013838; заявл. 22.11.2010; опубл. 25.06.2011, Бюл. № 12.

10. Доклінічні дослідження лікарських засобів : метод. рек. / за ред. О. В. Стефанова. - К. : Авіценна, 2001. - С. 528.

11. Брунь, Л. В. Розробка методики кількісного визначення диклофенаку натрію в плазмі крові щурів методом високоефективної рідинної хроматографії з урахуванням особливостей аналізу мікроконцентрації діючої речовини / Л. В. Брунь, С. М. Губарь // Укр. біофармац. журн. - 2016. - № 3 (44). - С. 54-59.

12. Реброва, О. Ю. Статистический анализ медицинских данных. Применение пакета программ Statistica / О. Ю. Реброва. - М. : МедиаСфера, 2006. $-312 c$

\section{REFERENCES}

1. Korzh, N. A. (2014). Ortopediia, travmatolohiia i protezirovanie - Orthopaedics, Traumatology and Prosthetics, 3, $144-145$.

2. de Rezende, M. U., de Campos, G. C., Pailo, A. F. (2013). Current concepts in osteoarthritis. Acta Ortop. Bras., 21 (2), $120-122$.

3. Kovalenko, V. N., Viktorov, A. P. (Eds.). (2015). Compendium 2015 - medications. Kyiv: Morion, 2320.

4. Korzh, N. A., Hvisyuk, A. N., Dedukh, N. V. et al. (2007). Osteoarthrosis: conservative therapy. N. A. Korzh, N. V. Dedukh, I. A. Zupanets (Eds.). Kharkov: Gold pages, 424.

5. Moskvin, S. V., Builin, V. A. (2006). Osnovy lazernoi terapii [Basics of laser therapy]. M.: Pyramid, 256.

6. Kamath, B. V. Shivram, K., Shah, A. C. (1993). High-perfomance liquid chromatographic method for the determination of diclofenac in human plasma and urine. J. Chromatogr., 12 (3), 324-329.

7. United States Pharmacopea. Official Monographs. (1995).

8. Brun, L. V., Macolinets, V. I., Gubar, S. N. (2016). Ukrainskyi biofarmatsevtychnyi zhurnal - Ukrainian biopharmaceutical journal, 4 (45), 62-70.

9. Korzh, M. O., Makolinets, V. I., Dedukh, N. V. et al. (2011). Method of complex conservative treatment of osteoarthrosis of the lower extremities joints. Patent of Ukraine on the useful model. 60579, IPC (2006) A 61 N 5/067, A 61 K 31/196, A 61 K 31/726. № u 201013838; declared 22.11.2010; published 25.06.2011, № 12 .

10. Stefanov, O. V. (Ed.). (2001). Doklinichni doslidzhennia likarskykh zasobiv [Preclinical studies of medicines]. Kyiv: Avicenna, 528.

11. Brun, L. V., Gubar, S. N. (2016). Ukrainskyi biofarmatsevtychnyi zhurnal - Ukrainian biopharmaceutical journal, 3 (44), 54-59.

12. Rebrova O. Yu. (2006). Statisticheskii analiz meditcinskikh dannykh. Primenenie paketa programm [Statistica Statistical analysis of medicals data. Statistica software package application]. Moscow: MediaSfera, 312.

\section{Information about authors:}

Brun L. V., c. biol. s., assistant professor, National University of Pharmacy. E-mail: Lidiiabrun@gmail.com

ORCID - http://orcid.org/0000-0002-5198-1027

Відомості про авторів:

Брунь Л. В., канд. біол. н., доцент, Національний фармацевтичний університет. E-mail: Lidiiabrun@gmail.com.

ORCID - http://orcid.org/0000-0002-5198-1027

Сведения об авторах:

Брунь Л. В., канд. биол. н., доцент, Национальный фармацевтический университет. E-mail: Lidiiabrun@gmail.com. ORCID - http://orcid.org/0000-0002-5198-1027

Рекомендовано д. мед. н., професором С. Ю. Штриголем

Надійшла до редакції 05.01.2017 р. 